\title{
The bright future of darkness-the rising power of black fungi: black yeasts, microcolonial fungi, and their relatives
}

\author{
G. Sybren de Hoog • Vania A. Vicente • \\ Anna A. Gorbushina
}

Received: 10 May 2013/Accepted: 10 May 2013/Published online: 29 May 2013

(C) Springer Science+Business Media Dordrecht 2013

Black fungi are no longer viewed as neglected, rare, or exotic fungi-in fact, we now realize that they are all around us on a daily basis. In the past, we just have been looking at the wrong places, with inadequate detection tools, or with inappropriate isolation methods. In a way, the seemingly ubiquitous presence of black fungi is disturbing, reflecting one of the bright/ dark contrasts of our research field: while scientists in the black yeast area all recognize the frustration of projects being rejected because of supposed societal insignificance, the general public tends to be afraid of these dangerous and omnipresent fungi. This fear dates back to 1934 when K. Kano described Hormiscium dermatitidis from a disfiguring facial infection in Japan. Since that time, many more severely mutilating and eventually fatal infections in apparently healthy

G. S. de Hoog ( $\square)$

CBS-KNAW Fungal Biodiversity Centre, Utrecht,

The Netherlands

e-mail: s.hoog@cbs.knaw.nl

\section{G. S. de Hoog}

Institute for Biodiversity and Ecosystem Dynamics,

University of Amsterdam, Amsterdam, The Netherlands

G. S. de Hoog

Research Center for Medical Mycology, Peking

University Health Science Center, Beijing, China

G. S. de Hoog

Sun Yat-Sen Memorial Hospital, Sun Yat-Sen University, Guangzhou, China people have been reported; the present issue of Mycopathologia contains another horrid example. Later, it was realized that these infections are related to diseases like chromoblastomycosis and primary cerebritis, which are already known for more than a century. Thus, severe black yeast diseases occurred long before organ transplantation was even invented, and in times when immune disorders like leukemia inevitably were rapidly followed by death. Black fungi belong to nature's repertoire of primary pathogens, it seems, because they are able to kill healthy and immunocompetent individuals.

But how come that we are still alive; why has humanity not been eradicated by these potent and widely dispersed organisms? The answer must be that pathogenicity in black fungi is mostly coincidental,

\author{
G. S. de Hoog \\ Shanghai Institute of Medical Mycology, Changzheng \\ Hospital, Second Military Medical University, Shanghai, \\ China \\ G. S. de Hoog · V. A. Vicente \\ Basic Pathology Department, Federal University \\ of Paraná State, Curitiba, Paraná, Brazil \\ G. S. de Hoog \\ King Abdulassiz University, Jeddah, Saudi Arabia
}

\section{A. A. Gorbushina}

Materials and Environment, Department of Earth Sciences \& Biology, Chemistry, Pharmacy, Freie Universität Berlin, Berlin, Germany 
and that the true ecological niche of many species lies somewhere else, outside the human host. In fact, the proportion of environmental black fungi with extraordinary survival capabilities but without pathogenic traits is overwhelmingly high in comparison with a relatively low number of pathogens. And perhaps even more important: not all fungi causing disease are pathogens. Some black fungi may have invasive abilities once they have reached our blood circulation, but they lack mechanisms to enter the tissue other than by accidental trauma-which would be a silly strategy for a true pathogen.

So where do they thrive? In fact, they are not common saprobes either. They are highly specialized in habitats which may be in our direct environment. Every tourist visiting a romantic city takes dozens of pictures of black yeasts back home, with black fungi covering the marble of ancient monuments bathed in sunlight. Numerous black fungi have a preference for strange, hostile, toxic, or extreme (micro)habitats. Exposed rock, but also mountain tops in the Antarctic and the Himalaya are covered by a stunning assortment of clumpy, jet-black organisms which have specialized to survive under conditions of high solar irradiation, high or low temperature, nutrient deficiency, or toxicity by hydrocarbons or heavy metals.

Given their prevalence, it is amazing that the knowledge of the diversity of black yeast-like fungi is only very recent. This is largely due to the fact that we have overlooked their existence in nature-mistaking black microcolonies for fly ash — and in the laboratory. We have been too impatient during isolation, when rapidly growing contaminants appear significantly earlier, long before the pinhead-sized black yeast colonies are recognizable. For a long time, there were also problems of distinguishing black fungi of different genera, as their reduced morphology did not allow proper identification. Novel diagnostic methodologies have contributed enormously to grasping the extant wealth of black yeast diversity. Full understanding their ecology and physiology is still longtime ahead.

Questions on ecology and evolution always generate exciting science. Where did the black yeasts come from, and what will be their evolutionary fate? Indications exist that in nutrient-deprived environments, many black fungi are inclined to form symbiotic relationships with their natural cohabitants like algae and cyanobacteria. They have survived over millions of years by exhibiting a highly simplified morphology. Others escape competition from adjacent microorganisms by inhabiting toxic micro-niches and are forced to adapt and evolve with changing conditions. A diversity of black fungal lifestyles has emerged, from symbiotic to free-living and pathogenic. The black yeasts present an evolutionary riddle that needs networking in a research community that accommodates divergent disciplines.

A first special issue on black yeasts was published by the Pan American Health Organization, dating back to 1977 , and has been very influential. Other journals, such as Antonie van Leeuwenhoek, Medical Mycology, Studies in Mycology, Fungal Biology and Fungal Diversity, have devoted special issues to this fascinating group of organisms. Concomitant with black yeast diversity, the nature of study areas is extremely varied. This is nicely reflected in the current issue of Mycopathologia, which was initiated after the workshop "Hidden Danger, Bright Promise," organized in Curitiba, Brazil, December 1-4, 2011, under the auspices of the International Society for Human and Animal Mycology (ISHAM). We are pleased to present you an issue with topics ranging from clinical sciences to rock-inhabiting, waterborne, and hydrocarbon-associated fungi. The joint research effort of the black yeast community generated a range of new topics that firmly "anchor" this group of organisms in a variety of significant microbiological and clinical study areas.

Several contributions in this issue of Mycopathologia concern the search for black fungi in humanmade or odd environments. The paper of Isola et al. [1] reports on automobile fuel tanks as a habitat, where black yeasts appear to be consistently present, suggesting a competitive advantage in habitats dominated by alkanes. Döğen et al. [2] focused on wooden railway ties in the hot climate of Southern Turkey. Railway ties bear fecal contamination, but are also rich in toxic hydrocarbons due to creosote treatment of the wood and leakage of machine oil from trains. Black yeasts are known to occur abundantly in oligotrophic water distribution systems. Heinrichs et al. [3] apply a novel pyrosequencing technique to determine the species composition in dark biofilms in a municipal drinking water system. Investigations of water systems on the air/solid/liquid interface $[4,5]$ and in mangrove habitats [6] reflect the fact the natural lifestyle of many black fungi is in biofilms.

The progress in our knowledge of the environmental presence of black fungi reflects our improved 
methodical skills in isolation and detection of these organisms. Especially underlined are new approaches to culture-independent identification of black fungi in human-made environments [4]. Clinical practice may profit from the development of diagnostic molecular methods like those of Hamzehei et al. [7], Badali et al. [8], and Santos et al. [9], while knowledge generated by Figel et al. [5] is significant to hospital hygiene. Duarte et al. [10] study the antifungal susceptibility of environmental species that may also be found as opportunists in human tissue. New and improved treatment options are discussed by Siqueira et al. [11] and Queiroz-Telles and Santos [12]. Expanded knowledge of uncommon clinical pictures are provided by Lu et al. [13], Bonifaz et al. [14], and Badali et al. [15].

Understanding of virulence factors is crucial to get a grip on the processes of evolution. Zhang et al. [16] studied the role of melanin in pathogenesis and immunostimulation in Fonsecaea agents of chromoblastomycosis with the aid of a non-melanized mutant. The authors revealed a dose-dependent impact of alkali/acid extracts of wild-type versus melanin-deficient mutant on the host's immune response. A causative analysis of the melanin function might stimulate the development of further diagnostic tools for clinical practice.

The simple morphology of rock-inhabiting fungi is only an external shell hiding a great variety of phylogenetic histories and lifestyles. A study of Muggia et al. [17] clarifies the phylogenetic position of Lichenothelia, a long-known genus with an amazing ecology and a lifestyle linking free-living rockinhabiting fungi to lichens. The complex and robust stress-tolerant physiology that exists inside of this simplified form is demonstrated by the physiological and proteome-based study of Zakharova et al. [18] The revealed differences between mesophilic (European origin) and extremotolerant (Antarctic origin) strains show physiological diversity that evolves under the circumstances of the geographic isolation coupled to extreme environmental influences.

The diversity of fungi and subjects in the present issue of Mycopathologia demonstrates that black yeasts have become very interesting models of study in a multitude of applied sciences. This is particularly due to their odd behavior in far from trivial habitats. At present, they are primarily renowned because of their ability to infect humans, but also the strictly nonpathogenic species possess interesting abilities which thus far are nearly unexplored. Black yeast research has a golden future.

\section{References}

1. Isola D, Selbmann L, de Hoog GS, Fenice M, Onofri S, FX, Prenafeta-Boldú, Zucconi L. Isolation and screening of black fungi as degraders of volatile aromatic hydrocarbons. Mycopathologia. 2013. doi:10.1007/s11046-0139635-2.

2. Döğen A, Kaplan E, Ilkit M, de Hoog GS. Massive contamination of Exophiala dermatitidis and E. phaeomuriformis in railway stations in subtropical Turkey. Mycopathologia. 2013. doi:10.1007/s11046-012-9594-z.

3. Heinrichs G, Hübner I, Schmidt CK, de Hoog GS, Haase G. Analysis of black fungal biofilms occurring at domestic water taps. I. Compositional analysis using Tag-Encoded FLX Amplicon Pyrosequencing. Mycopathologia. 2013. doi:10.1007/s11046-013-9618-3.

4. Heinrichs G, Hübner I, Schmidt CK, de Hoog GS, Haase G. Analysis of black fungal biofilms occurring at domestic water taps (II) Potential routes of entry. Mycopathologia. 2013. doi:10.1007/s11046-013-9619-2.

5. Figel IC, Dantas Marangoni PR, Tralamazza SM, Vicente VA, do Rocio Dalzoto P, Fidelis do Nascimento MM, de Hoog GS, Pimentel IC. Black yeasts-like fungi isolated from dialysis water in hemodialysis units. Mycopathologia. 2013. doi:10.1007/s11046-013-9633-4.

6. Guerra RS, Fidelis do Nascimento MM, Miesch S, Najafzadeh MJ, Orélis Ribeiro R, Ostrensky A, de Hoog GS, Vicente VA, Boeger WA. Black yeast biota in the mangrove, in search of the origin of the Lethargic Crab Disease (LCD). Mycopathologia. 2013. doi:10.1007/s11046-0139636-1.

7. Hamzehei H, Yazdanparast SA, Khodavaisy S, Golehkheyli M, Ansari S, de Hoog GS, Badali H. Use of rolling circle amplification to rapidly identify species of Cladophialophora potentially causing human infection. Mycopathologia. 2013. doi:10.1007/s11046-013-9630-7.

8. Badali H, Fernández González M, Mousavi B, Illnait-Zaragozi MT, González Rodríguez JC, de Hoog GS, Meis JF. Chromoblastomycosis due to Fonsecaea pedrosoi and $F$. monophora in Cuba. Mycopathologia. 2013. doi:10.1007/ s11046-013-9634-3.

9. Santos DWCL, Padovan ACB, Melo ASA, Gonçalves SS, Azevedo VR, Ogawa MM, Sandes Freitas TV, Colombo AL. Molecular identification of melanised non-sporulating moulds: A useful tool for studying the epidemiology of phaeohyphomycosis. Mycopathologia. 2013. doi:10.1007/ s11046-012-9608-x.

10. Duarte APM, Pagnocca FC, Baron NC, de Souza Carvalho Melhem M, Palmeira GA, de Franceschi de Angelis D, Attili-Angelis D. In vitro susceptibility of environmental isolates of Exophiala dermatitidis to five antifungal drugs. Mycopathologia. 2013. doi:10.1007/s11046-012-9597-9.

11. Siqueira IM, Melo Ribeiro A, de Medeiros Nóbrega YK, Smidt Simon K, Oliveira Souza AC, Souza Jerônimo M, Cavalcante Neto FF, Lopes Silva C, Soares Felipe MC, 
Bocca AL. DNA-hsp65 vaccine as therapeutic strategy to treat experimental chromoblastomycosis caused by Fonsecaea pedrosoi. Mycopathologia. 2013. doi:10.1007/s11046012-9599-7.

12. Queiroz-Telles F, Santos DWCL. Challenges in the therapy of chromoblastomycosis. Mycopathologia. 2013. doi:10.1007/ s11046-013-9648-x.

13. Lu S, Lu CM, Zhang JM, Hu YX, Li XQ, Xi LY. Chromoblastomycosis in mainland China: a systematic review on clinical characteristics. Mycopathologia. 2013. doi:10.1007/s11046-012-9586-z.

14. Bonifaz A, Davoudi MM, de Hoog GS, Padilla-Desgarennes C, Vázquez-González D, Navarrete G, Meis JF, Badali H. Severe disseminated phaeohyphomycosis in an immunocompetent patient caused by Veronaea botryosa. Mycopathologia. 2013. doi:10.1007/s11046-013-9632-5.

15. Badali H, Yazdanparast SA, Bonifaz A, Mousavi B, de Hoog GS, Klaassen CHW, Meis JF. Veronaea botryosa:
Molecular identification with Amplified Fragment Length Polymorphism (AFLP) and in vitro antifungal susceptibility. Mycopathologia. 2013. doi:10.1007/s11046-0139631-6.

16. Zhang J, Wang L, Xi LY, Huang HQ, Hu YX, Li XQ, Huang $\mathrm{X}$, Lu S, Sun JF. Melanin in a meristematic mutant of Fonsecaea monophora inhibits TH1 cytokines and nitric oxide production of murine macrophages. Mycopathologia. 2013. doi:10.1007/s11046-012-9588-x.

17. Muggia L Gueidan C, Knudsen K, Perlmutter G, Grube M. The lichen connections of black fungi. Mycopathologia. 2013. doi:10.1007/s11046-012-9598-8.

18. Zakharova K, Tesei D, Marzban G, Dijksterhuis J, Wyatt T, Sterflinger K. Microcolonial fungi on rocks: A life in constant drought? Mycopathologia. 2013. doi:10.1007/s11046012-9592-1. 